\title{
AOR
}

Selected Papers of \#AolR2019:

The $20^{\text {th }}$ Annual Conference of the Association of Internet Researchers

Brisbane, Australia / 2-5 October 2019

\section{THE AFTERLIVES OF MEMORIAL MATERIALS: DATA, HOAX, BOT}

The study of death online regularly intersects with questions of trust, though such questions have evolved over time to not only include relations of trust between individuals and trust within online communities, but also issues of trust emerging through entanglements and interactions with the memorial materials, and their afterlives. Papers in this panel attend to issues of trust in our relations with the afterlives of digital data, the circulation of fake deaths, the care attached to memorial bots, and the intersection of robots and funerals.

Over the last twenty years the study of death online developed into a diverse field of enquiry. Early literature addressed the emergence of webpages created as online memorials and focused on their function to commemorate individuals by extending memorial artefacts from physical to digital spaces for the bereaved to gather (De Vries and Rutherford, 2004; Roberts, 2004; Roberts and Vidal, 2000; Veale, 2004). The emergence of platforms for social networking in the mid-2000s broadened the scope of research to include increasingly knotted questions around the ethics, politics and economics of death online. Scholars began investigating issues like the performance of public mourning, our obligations to and management of the digital remains of the deceased, the affordances of platforms for sharing or trolling the dead, the extraction of value from the data of the deceased, and the ontology of entities that digitally persist (e.g. Brubaker and Callison-Burch, 2016; Gibbs et al., 2015; Karppi, 2013; Marwick and Ellison, 2012; Phillips, 2011; Stokes, 2012).

Scaffolding this scholarship are a number of research networks, including the Death Online Research Network and the DeathTech Research Network, who encourage international collaboration and conversation around the study of death and digital media, including supporting this AoIR panel. This panel challenges us to go beyond a focus on the commemoration of humans to encompass a broader set of materialities in the field of research on death and digital media. Digital residues of the deceased persist within and circulate through online spaces, enrolling users into new configurations of posthumous dependence on platforms, whilst at the same time digital afterlives now intersect with new technologies to create emergent forms of agency such as chatbots and robots that extend beyond the human, demanding to be considered within the

Nansen, B. Hjorth, L. Pitsillides, S. and Gould, H. (2019, October 2-5). The Afterlives of Memorial Materials: Data, Hoax, Bot. Panel presented at AolR 2019: The $20^{\text {th }}$ Annual Conference of the Association of Internet Researchers. Brisbane, Australia: AolR. Retrieved from http://spir.aoir.org. 
sphere of digital memorialisation. Questions of trust emerge in this panel through various kinds of relationality formed with and through digital remains. These extend from relations of trust in the digital legacies now archived within platform architectures and how we might curate conversations differently around our personal data; to the breaking of trust in the internet when creating or sharing a hoax death; to the trust involved in making and caring for a posthumous bot; to the trust granted to robots to perform funerary rites.

It is anticipated that this panel will not only appeal to scholars interested in the area of death and digital media, but also engage with broader scholarly communities in which questions of death now arise in larger debates around data, materiality, and governance on and of the internet.

\section{References}

Brubaker, J. R. and Callison-Burch, V. (2016) Legacy Contact: Designing and Implementing Post-mortem Stewardship at Facebook. Paper presented at CHI Workshop on Human Factors in Computer Systems, San Jose California.

de Vries, B. and Rutherford, J. (2004) Memorializing Loved Ones on the World Wide Web. Omega: Journal of Death and Dying, 49(1), 5-26.

Gibbs, M., Meese, J., Arnold, M., Nansen, B., and Carter, M. (2015) \#Funeral and Instagram: Death, Social Media and Platform Vernacular. Information Communication and Society, 18(3): 255-268.

Karppi, T. (2013) Death proof: on the biopolitics and noopolitics of memorializing dead Facebook users. Culture Machine, 14, 1-20.

Marwick, A. and Ellison, N. (2012) "There Isn't Wifi in Heaven!" Negotiating Visibility on Facebook Memorial Pages. Journal of Broadcasting and Electronic Media 56(3), 378400.

Phillips, W. (2011) LOLing at Tragedy: Facebook Trolls, Memorial Pages and Resistance to Grief Online. First Monday 16(12). Retrieved from http://firstmonday.org

Roberts, P. (2004) The Living and the Dead: Community in the Virtual Cemetery. Omega: Journal of Death and Dying, 49(1), 57-76.

Stokes, P. (2012) Ghosts in the Machine: Do the Dead Live on in Facebook? Philosophy and Technology, 25(3), 363-379.

Veale, K. (2004) Online Memorialisation: The Web as a Collective Memorial Landscape For Remembering The Dead. The Fibreculture Journal, 3. Retrieved from http://three.fibreculturejournal.org. 


\title{
AOR
}

Selected Papers of \#AolR2019:

The $20^{\text {th }}$ Annual Conference of the

Association of Internet Researchers

Brisbane, Australia / 2-5 October 2019

\section{THEY SAY THE FUTURE IS DEATH: \#DEARFUTURECITIZEN}

\author{
Larissa Hjorth \\ RMIT University
}

In a few years, Facebook will have more dead than living users. What does it mean to live with data of the dead haunting us every day? How does trust operate in such a space? And how are everyday citizens thinking about digital legacy provision (i.e who will steward your data when you are dead)?

In recent times there has been a growth of work considering the potential implications of our digital legacy (Kaskett forthcoming; Gibbs et al., 2015). We are seeing older interactions between technology and death (such as the role of the camera in memorial practices) being renewed through social media practices (for example, funeral selfies [Meese et al., 2015]). At the same time, social media opens up new avenues for experiencing death and loss, from accessing Facebook tribute pages during public disasters to the lingering digital traces on a smartphone of someone deceased (Gibbs et al., 2015; Brubaker et al., 2012; Graham et al., 2013; Lingel, 2013; Church, 2013; Deger, 2008, 2006; Gibson, 2015, 2008; Gibbs et al., 2015b; Refslund Christensen and Gotved, 2014).

Social and mobile media are having a substantial impact on the way we think about and deal with death, loss and grief. Our relationship with social media and the mobile devices we use to access social media and the array of other attendant media technologies can often be best characterised through understanding a series of intimate relationships (Hinton and Hjorth 2013). Often these relationships are considered with respect to the living, but increasingly we need to consider the implications of the intimacy associated with social and mobile media, and how we use these to relate to death and loss.

Digital data allow for new ways to think about, configure and contextualise death (Gotved, 2014; Baumer et al., 2015). Much of the literature around the way that digital media has changed our relationship with death has focused upon online memorials (de Vries and Rutherford, 2004) and other forms of grieving online (Veale, 2003).

Hjorth, L. (2019, October 2-5). The Future is Death: \#Dearfuturecitizen. Paper presented at AolR 2019: The $20^{\text {th }}$ Annual Conference of the Association of Internet Researchers. Brisbane, Australia: AolR. Retrieved from http://spir.aoir.org. 
Researchers are now beginning to go further and are looking at the way engagement with death online is complicated due to the way that our online and offline lives have become entangled through social and mobile media, and thus necessarily also rituals and processes around death, dying and after-death (Graham et al., 2013). Where Victorian rituals of death (Walter et al., 2011) once compartmentalised death to the grave, and psychological models have constructed grief as something that one can "get over" (Rosenblatt, 1996), the everydayness of digital media see that "death and (after-) death are, once again, becoming more public and everyday" (Graham et al., 2013: 136).

Mobile and social media bring together a series of unique affordances that not only contextualise death within the everyday, but does so in more immediate and personal ways. Our devices don't just mediate death and its attendant rituals, but also remediate and mediatise, allowing for the emergence of different interactions between individuals, intimate publics, peri-mortem and post-mortem rituals. This phenomenon can be understood in terms of Digital Afterlife.

\section{The Digital Afterlife}

In the past when a loved one passed away, those left behind continue to have duties to the deceased. Material possessions are sorted, sold, gifted, and traces of the deceased such as photos or the most personal possessions are stored as memorial keepsakes. Today it is hard not to leave a digital footprint. Many people have at least one social media profile, and as we increasingly use technologies like wearables to track our behaviour, and even as our consumption moves from physical media, to broadcast and live streaming media, we accrue a digital presence, replete with digital possessions and us-shaped data patterns in the digital firmament. What happens to these digital possessions and traces that defined a person in life? What are the issues we need to consider in the digital afterlife?

Graham et al. have argued new media are changing our relationship with life and death. They are enabling new modes for life to be "extended, prolonged and ultimately transformed through the new circulations, repetitions, and recontextualizations on the Internet and other platforms" (2013: 133). Digital data allow new ways in which to construct one's life, death and after-death (Stanyek and Piekut, 2010; de Vries and Rutherford, 2004; Veale, 2003; Bollmer, 2013; Bennett and Bennett, 2000; Jones, 2004). Mobile media can play a role as a witness, repository, disseminator and magnifier of events. However, we are also seeing the development of novel ways to engage with death at a personal level through social media, with new genres such as "selfies at funeral" signalling emergent relations between intimacy, mobile media, etiquette and affect (Meese et al., 2015; Gibbs et al., 2015).

Through its assemblage of intimate and yet public textures, mobile media makes us reconsider the relationship between death and afterlife, especially with the digital afterlife and posthumous performativity still relatively underexplored (Stanyek and Piekut, 2010). As Refslund Christensen and Gotved observe, "media are materialities that allow us to communicate with the dead or about the dead over the gaps between the world of the living and whatever spatial and temporal sphere the dead may reside without being absorbed into these gaps ourselves" (2015: 1). These materialities 
potentially includes a vast range of digital possessions and derived data, ranging from social media accounts to music collections, from collected data such as exercise and other QS data to all manner of things which are now stored on the cloud. These media materialities provide often significantly intimate connections with the deceased, and raise important questions about what is to be done with this data, and who should make decisions about that data on behalf of the dead. We are now witnessing the rise of digital afterlife roles such as "stewarding" (or managing online media of a posthumous loved one) that involves often invisible and yet symbolic practices not often acknowledged in visual labour of social media (Brubaker, 2016).

This talk explores how we might curate conversations differently around data of dead. It draws on an art installation entitled \#dearfuturecitizen (RMIT Gallery Feb 2019) that asked audience members to sit on a fake island and contemplate the future of data in their life. Through postcard prompts, audience participants are asked to write on a postcard their hopes and fears for the future of data. It seeks to ask: how should living with data of the dead look and feel like?

The postcards were then documented through social media \#dearfuturecitizen to curate a space for sharing these stories and hopes online. This talk explores how creative methods and modes of knowledge exchange might create (and curate) a deeper understanding into these cofuturing issues around trust, data and death.

\section{References}

Bollmer, G. (2013) Millions Now Living Will Never Die: Cultural Anxieties About the Afterlife of Information. The Information Society, 29(3), 142-151.

Brubaker, J. R. (2016, June 13) Stewarding someone else's self: A study of stewardship experiences of post-mortem profiles on Facebook. Paper presented at the International Communication Association Annual Conference in Fukuoka, Japan.

Brubaker, J., Ananny, M., and Crawford, K. (2014) Departing glances: A sociotechnical account of 'leaving' Grindr. New Media and Society, 18(3), 373-390.

Brubaker, J. R., Dombrowski, L., Gilbert, A., Kusumakaulika, N., and Hayes, G. R. (2014) Stewarding a legacy: Responsibilities and relationships in the management of post-mortem data. Proc.CHI 2014. Toronto, Canada. April 26-May 1.

Cumsikey, K. and L. Hjorth (2018) Haunting Hands. Oxford: Oxford Uni Press.

Gibbs, M., Meese, J., Arnold, M., Nansen, B., and Carter, M. (2015b) \#Funeral and Instagram: Death, social media, and platform vernacular. Information, Communication and Society, 18(3), 255-68.

Gibson, M. (2015) Automatic and automated mourning: messengers of death and messages from the dead. Continuum, 29(3), 339-353. 
Gotved, S. (2014) Research Review: Death Online - Alive and Kicking! Thanatos, 3(1), 112-180. Retrieved from

https://thanatosjournal.files.wordpress.com/2012/12/gotved_deathonline2.pdf

Graham, C., Gibbs, M., and Aceti, L. (2013) Introduction to the special issue on the death, afterlife, and immortality of bodies and data. The Information Society, 29(3), 133141.

Hinton, S., and Hjorth, L. (2013) Understanding Social Media. London: Sage.

Hoskins, A. (2011) Media, memory, metaphor: Remembering and the connective turn. Parallax, 17(4), 19-31.

Jones, Steve. (2004) 404 not found: The internet and the afterlife. Omega: Journal of Death and Dying, 49(1), 83-88.

Kohn, T., Nansen, B., Arnold, M., and Gibbs, M. (2012) Facebook and the other: Administering to and caring for the dead online. In G. Hage (Ed.), Responsibility (pp. 128-141). Melbourne: University of Melbourne Press.

Leaver, T. (2013) The Social Media Contradiction: Data Mining and Digital Death, M/C Journal, 16(2) - 'mining'. Retrieved from http://journal.mediaculture.org.au/index.php/mcjournal/article/view/625

Lingel, J. (2013) The digital remains: Social media and practices of online grief. The Information Society: An International Journal, 29(3), 190-195.

Meese, J., Gibbs, M., Carter, M. et al. (2015) Selfies at Funerals: Mourning and Presencing on Social Media Platforms. International Journal of Communication, 9(1), 1818-1831.

Nansen, B., Arnold, M., Gibbs, M., and Kohn, T. (2014) The restless dead in the digital cemetery. In C. Moreman and Lewis, A. (Eds.), Digital Death: Mortality and Beyond in the Online Age (pp. 111-124). Westport: ABC-CLIO, LLC.

Papailias, P. (2016) Witnessing in the age of the database: Viral memorials, affective publics, and the assemblage of mourning. Memory Studies, 9(4), 437-454.

Refslund Christensen, D., and Gotved, S. (2014) Online memorial culture: An introduction. New Review of Hypermedia and Multimedia, 21(1-2), 1-9. 


\title{
AOR
}

Selected Papers of \#AolR2019:

The $20^{\text {th }}$ Annual Conference of the

Association of Internet Researchers

Brisbane, Australia / 2-5 October 2019

\section{“I'M BOUT TO GET THIS TRENDING...”: FAKE DEATHS ON TWITTER}

\author{
Bjorn Nansen, Dominic O’Donnell, Michael Arnold, Tamara Kohn, Hannah Gould, \\ Martin Gibbs \\ The University of Melbourne
}

\section{Introduction and Background}

On the $23^{\text {rd }}$ of February 2015, a rumour began circulating on Twitter that singer Beyoncé Knowles had died, resulting in "\#RIPBeyonce" trending. The rumour began with a user, @MattMcGrail, deliberately starting the hashtag, tweeting "I'm bout to get this trending... \#RIPBeyonce" (8:19 PM - 23 Feb, 2015). The hoax quickly spread with numerous users tweeting the news via the hashtag, and as the initial tweet gained more feedback (i.e., replies/retweets/likes), the hashtag trended and there emerged a diversity of user responses, spreading from grief, to doubt, to more critical and cultural commentary on the phenomenon of fake death announcements online.

Media have long operated as a means of both memorializing and communicating death (e.g., Arnold et al., 2018; Jones 2004). Print enabled a death notice posted in a public place or an obituary in a newspaper to circulate widely than (Starck, 2006). More recently, death notices have spread beyond the classified sections of newspapers, via the internet and social media, eroding social, geographic and temporal limitations in communicating news of the deceased. This has, in turn, amplified possibilities for fake or premature announcements of death to be produced and distributed.

In this paper, we analyse fake death announcements of public figures on social media, and the public responses to them. We identify a pattern of user responses, which cycle through more expected reactions from sharing the news, to grief, to uncertainty and disbelief. But we also identify more critical and culturally oriented responses to such death announcements. These responses offer critiques of the context of this phenomenon in relation to either the quality of digital news or to cultures of social media. Such critiques raise questions about the viral and performative qualities of both public mourning and expressions of cultural capital in public responses to fake death announcements.

Nansen, B. O'Donnell, D. Arnold, M. Kohn, T, Gould, H, and Gibbs, M. (2019, October 2-5). "I'm bout to get this trending...": Fake deaths on Twitter. Paper presented at AolR 2019: The $20^{\text {th }}$ Annual Conference of the Association of Internet Researchers. Brisbane, Australia: AoIR. Retrieved from http://spir.aoir.org. 


\section{Research approach}

This analysis draws from a range of public sources to collect and categorise the volume of fake death announcements noted on Twitter - see Table 1 for types. We then conducted a case study analysis of representative examples of these different types of fake death using Twitter's Advanced Search feature to collect data on the timeline, posts, and reactions to these fake announcements - see Table 1 for cases studies. This analysis is briefly summarised below.

Table 1: Types, and case studies of fake death announcements

\begin{tabular}{|l|l|}
\hline Type/definition & Case studies \\
\hline $\begin{array}{l}\text { Accidental: inadvertent release of drafted obituaries } \\
\text { or death announcement }\end{array}$ & Prince Philip (2017) \\
\hline $\begin{array}{l}\text { Misreport: unintentional misreporting by news } \\
\text { account (often misinterpreted illness or near death) }\end{array}$ & Tom Petty (2017) \\
\hline $\begin{array}{l}\text { Misunderstanding: unintentional misreport by } \\
\text { social media user }\end{array}$ & Gene Hackman (2015) \\
\hline $\begin{array}{l}\text { Hacking: account of public figure or news outlet } \\
\text { hacked, and fake death deliberately posted }\end{array}$ & Jack Black (2016) \\
\hline $\begin{array}{l}\text { Hoax: deliberate fake report made on social media } \\
\text { as prank or scam }\end{array}$ & $\begin{array}{l}\text { Beyoncé (2015) } \\
\text { Brad Pitt (2016) }\end{array}$ \\
\hline
\end{tabular}

\section{Discussion}

Inadvertent fake announcements

Inadvertent types of publicly announced death announcements include accidental, misreporting, and misunderstanding. For example, most accidental publications of draft obituaries come from news websites, such as The Sun accidentally publishing a drafted obituary of Prince Philip in 2017. Misreported deaths typically result from misinterpretation of a reported illness or brush with death, such as when CBS News prematurely announced in 2017 that Tom Petty had died after he went into cardiac arrest. Misunderstood deaths often result from a user posting a death announcement after misunderstanding news information, such as pop-culture blog Grantland posting an article in 2017 on Gene Hackman's retirement from acting with the vague use of the word 'gone' in the headline "The Greatest Living American Actor at 85: Gene Hackman is Gone but Still in Charge".

\section{Deliberate fake announcements}

In contrast, deliberate hoax death announcements mostly functioned as a prank as in the case of Beyoncé, but also for more malicious purposes, such as phishing scams, as in the case of a fake news article claiming Brad Pitt had suicided in 2016. Other deliberate fake deaths use hacked social media accounts of a public figure or news provider. For example, in 2016, @Ruthless hacked the account of Jack Black's band Tenacious D (@RealTenaciousD) and posted the false claim that Black had died. 
On Twitter, these announcements typically cycle through a pattern of personal and affective responses, with initial posts reporting the event or expressing grief. Another set of tweets express uncertainty, confusion or doubt about the event. Users question the veracity of the story based on the source of the announcement, or try to debunk rumours by reference to other reporting or authoritative sources:

- “Did Gene Hackman die? I just saw @DylanMcDermott post that he did but I can't find proof on the internet. Another \#celebritydeathhoax?" (@heathercnick, 27 Jan 2015)

- “Tom Petty didn't die? His daughter posted on Instagram that he's still alive. Come on fam." (@__PantheR, 3 Oct 2017, 3 replies, 7 retweets, 18 likes)

Beyond this clear pattern, we also saw two key threads of user commentary and critique emerge around fake deaths.

Commentary on fake deaths

Critical responses to the more inadvertent types of fake death focused on the deterioration of journalism in digital spaces, accusing both individual journalists - as in the disapproval of Grantland for its vague headline - and news organisations or media more generally of poor quality journalism for prematurely (mis)reporting a death in the rush to publish first:

- "So Grantland puts up a confusing headline that presumes Gene Hackman is dead and it goes viral. Click-bait has once again reached a new low." (@sleepyskunk, 28 Jan 2015)

- "Unsure if Tom Petty is actually dead. However I'm very sure that 'Getting it right over getting it first' journalism is." (@cathrynlavery, 3 Oct 2017, 1 retweet, 8 likes)

In contrast, critical responses to deliberate types of fake death (hoax, hacking), were directed at social media platforms for enabling fake deaths to be generated and circulated, or at cultures of social media use contributing to the frequency of instances and persistence of rumours surrounding fake deaths:

- “Just a meme bro" (@RealTenaciousD, 5 Jun 2016, feedback data not available)

- "I love when Twitter kills off celebrities \#RIPBeyonce" (@loveyahbrooke, 8:53 PM - 23 Feb 2015, 1 like)

- "There's always a couple of friends who are first with the "RIP celebrity" post on FB.. Just waiting them to fall for the Jack Black hoax!" (@QN1981, 2 likes)

- "The Jack Black death hoax proves one thing. Children and idiots should not be allowed to use the Internet unsupervised! That is all." (@OriginalKrush, 5 Jun 2016, 1 like)

Users often deployed humour as a form of social commentary about the operation of fake deaths within internet culture, and topics ranging from fake news, to celebrity, to contagion, to memes (Phillips and Milner, 2017). Here, the 'spreadability' (Jenkins, 2013) of fake deaths is facilitated through platform affordances and features such as hashtags; whilst the culture of 'viral performativity' in pubic mourning (Mitchell et al., 
2016) is subverted and critiqued as a way to assert one's digital literacy and cultural capital.

\section{References}

Arnold, M., Gibbs, M., Kohn, T., Meese, J., and Nansen, B. (2018) Death and Digital Media. Routledge.

Jenkins, H. (2013) Spreadable Media: Creating Value and Meaning in a Networked Culture. New York: New York University Press.

Jones, S. (2004) 404 not found: The Internet and the afterlife. Omega, Journal of Death and Dying, 48(1), 83-88.

Karlsson, M. (2011) The immediacy of online news, the visibility of journalistic processes and a restructuring of journalistic authority. Journalism 12(3), 279-95.

Mitchell, P., Axel, B., and Münch, F. (2016) The (net)work of mourning: Emotional contagion, viral performativity, and the death of David Bowie. In proceedings of The 17th Annual Conference of the Association of Internet Researchers, 1-2.

Phillips, W., and Milner, R.M. (2017) The Ambivalent internet: Mischief, oddity, and Antagonism Online. Polity Press.

Starck, N. (2006) Life after death: The art of the obituary. Melbourne University Publishing. 


\title{
AOR
}

Selected Papers of \#AolR2019:

The $20^{\text {th }}$ Annual Conference of the Association of Internet Researchers

Brisbane, Australia / 2-5 October 2019

\section{CARE BETWEEN HUMANS AND NON-HUMANS: MATERIAL/ MAKING/ MEMORIALISATION}

\author{
Dr Stacey Pitsillides \\ University of Greenwich
}

Care is a concept that has strong interdisciplinary qualities and deep roots as a mode of inquiry. When framed as a research question care can be used a method to draw together different disciplines such as philosophy (Kirkegard, 2009 [1938]), nursing (Dyson, 1996) and design (Latour, 2008) into a productive dialogue. The move towards a person-centred approaches [client-centred theory] in hospice care and user-centred or human-centred design principles, put the human holistically at the heart of the product, service or system. However, what happens to these approaches when involving nonhumans in networks of care?

Consider the word care, etymologically it embodies strong links to grief ${ }^{1}$ but was defined (1580s) as an "object or matter of concern" (https://www. etymonline.com/word/care). Exploring how care can be informed by grief through an object highlights the deep connection between human and non-human actors. It connects to Latour's (2008) use of things as gatherings to open up a theory of design as engagement, including: "care, precautions, skills, crafts, meanings, attention to details ... [and] careful conservations" (p.7). This paper extends Latour's research, questioning how care is activated and situated within networks when creating memorial bots and activating twitter-based tributes.

\section{The Material of Care: Making as an Expression of Care}

Considering the work of Søren Kierkegaard (1938) the link between labour and care provides a conducive platform for understanding the transformation of material things into matters of concern, for example the woman making an altar cloth works:

\footnotetext{
${ }^{1}$ Old English caru, cearu "sorrow, anxiety, grief" and Proto-Germanic karō "lament; grief, care." Pitsillides, S. (2019, October 2-5). Care between Humans and Non-humans: Material/ Making/ Memorialisation. Paper presented at AolR 2019: The $20^{\text {th }}$ Annual Conference of the Association of Internet Researchers. Brisbane, Australia: AolR. Retrieved from http://spir.aoir.org.
} 
"day and night for her ... beloved work. But when the cloth is finished and put to its sacred use: then she is deeply distressed if someone should make the mistake of looking at her art... instead of the meaning of the cloth. For she could not work the sacred meaning into the cloth itself, nor could she sew it onto the cloth as though it were one more ornament." (Kierkegaard, 2009: 13)

This statement explores how the material qualities of making are used critically to embed meaning into something beyond ourselves. In design this form of care is a creative practice that produces critical and situated reflections (Suchman, 2002). Mol (2008) states "good care is ... something that grows out of collaborative and continuing attempts to attune knowledge and technologies to diseased bodies and complex lives" (Loc 11), while Gunaratnam (2007) reflects on her practice of constructing poems that respond to pain. Her practise of caring for the data and the people interviewed creates an emotional response, which is ethically situated and corporally felt. Mol and Gunaratnam share an approach to care as a responsive process, similar to the attempt to embed spirituality into alter cloth. Rather then imposing our will on materials, we are in correspondence with them (Ingold, 2013: 31) crafting code in response to "material, humanity, and environment" (Richardson (2005: 157) that allows online or digital making to be situated within the technological system enhancing the agency of the dead and our trust in the technologies that produce them.

\section{Constructing Care: Dadbot and \#ThatDragonCancer}

The Dadbot project documents the life of Noah's farther with stage IV lung cancer transforming overtime into a project to distil his father's biographical narrative (Walter, 1996) into a bot. Making the bot was a way of spending time with his father during his death and posthumously. In WIRED's short film $(2017)^{2}$ Noah describes making the bot as a way of 'being' with his father after death. His solace was that "the Dadbot's digital brain has [his] dad's real words" (0:50-0:58). During the process of the oral history he recorded 91,970 words that needed to be pattern matched through artificial intelligence and it is through this reassembly that the network is revealed. There is a reciprocal relationship demonstrated here. Through interacting, the Dadbot takes care of Noah by singing (0:22), chatting and revealing particular links to memories and he takes care of the Dadbot through working on the code that constructs it. There is a trust placed in the way that the technology illuminates the playfulness of their relationship. However, it is when it breaks down that its agency is revealed for example when it doesn't say 'I love you.' Noah reflects:

"I was disappointed in the Dadbot when he didn't say he loved me back... on two levels, one just the technological, like Dadbot your supposed to know that... but, its fake and yet I wanted to hear it even though I am making it, it still feels nice to me if my dad says something personal to me" $(6: 46-7: 14)$

\footnotetext{
${ }^{2}$ https://www.youtube.com/watch?v=0Q7V74s6e04
} 
However, there is something in the error of recognition that reveals a very human quality. Through his fathers lack of response, he is able to question his relationship within the technological system.

\#ThatDragonCancer I hope there was a pancake party in heaven yesterday for Joel. Thanks Amy and Ryan Green!
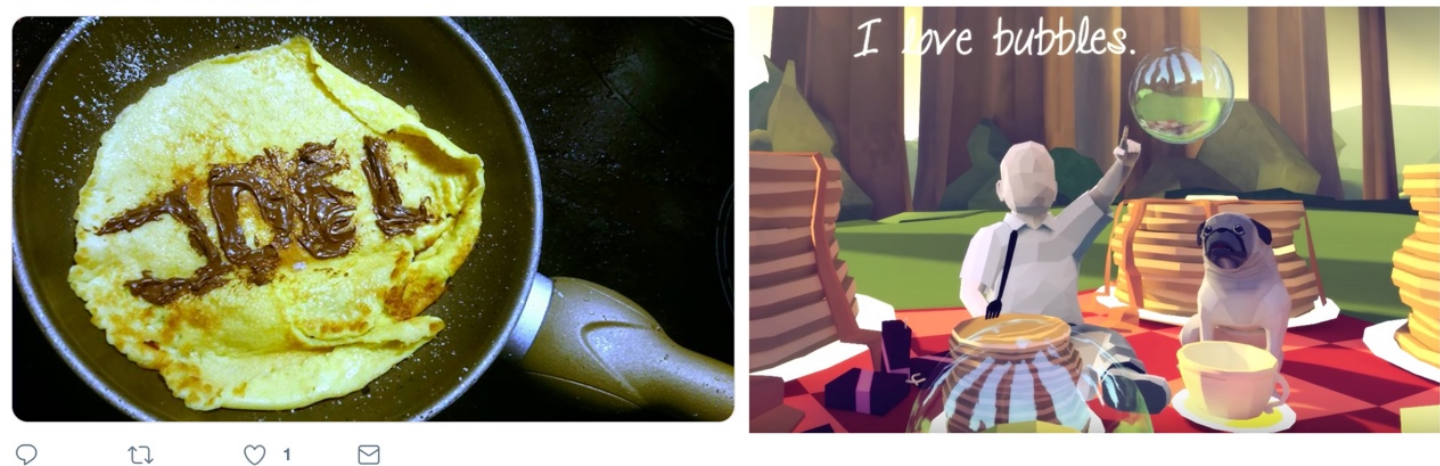

Figure 1: A tweet from the worldwide pancake party \#ThatDragonCancer (left) and a screen shot from closing scene of the game That Dragon Cancer (right).

In contrast to the Dadbot being a collection of Noah's father, That Dragon, Cancer is computer game made as a tribute to the life of Joel Green who died of cancer at the age of five. The game navigates a range of surreal environments showing the various stages of cancer's infiltration into the Green's lives. The game is a form of care as an expression of love and loss. It gives their sons story the agency to extend his presence beyond his short life. His mother's words on their blog give some insight into this: "He might not have had a job, or a wife, but he did impact the world, because he impacted us"3.

The game ends with a scene called the Pancake Party (Figure 1) that is a 3D manifestation of all the things that Joel loved, set up as an interactive collage with oversized pancakes and blowable bubbles. These digital things confirm Joel's childlike desires and his families need to continue bonds through the things he loved. The pancakes are expanded as a network through launching the game with a worldwide pancake party for Joel on Twitter. This act of eating pancakes and writing messages for the family extends the final scene of the game into the material world, sharing the labour of making pancakes and the results as a multisensory digital memorial - a collection of care and an act of collective care that the family entrusts to this digital community.

\section{Conclusion}

Considering Dadbot and the Twitter Pancake Party, this paper considers how we may explore sites of digital care holistically beyond their products. Both examples encompass a tangible link to how the practice of making is embedded into the creative interpretation, past and present. The Pancake Party on Twitter constructs a shared act

${ }^{3}$ http://www.thatdragoncancer.com/thatdragoncancer/2015/12/28/pancakes-for-dinner-summarizing-a-lifecut-short 
of eating that creates an online space for taking care of the bereaved family. Dadbot shows a correspondence of care and trust between humans and non-humans that embodies externalisation of conversations with the dead. Together they activate the role of things, materials and practices in relation to caring for the dead digitally.

\section{References:}

Dyson, J. (1996). Nurses' conceptualizations of caring attitudes and behaviours. Journal of Advanced Nursing, 23(6), 1263-1269.

Gunaratnam, Y., (2007). Where is the love? Art, aesthetics and research. Journal of Social Work Practice, 21(3), p.271-287.

Ingold, T. (2013). Making: Anthropology, archaeology, art and architecture. Routledge.

Kierkegaard, S. (2009). Purity of Heart is to Will One Thing. Feather Trail Press: USA

Latour, B., (2008). A cautious prometheus? A few steps toward a philosophy of design. In Proceedings of the 2008 conference of the design history society (p. 2-10).

Mol, A. (2008). The logic of care: Health and the problem of patient choice. Routledge.

Richardson, A., (2005). New media, new craft. In Proceedings of the International Conference on Computer Graphics and Interactive Techniques (p.157-159).

Suchman, L. (2002). Located accountabilities in technology production. Scandinavian journal of information systems, 14(2), 7.

Walter, T., (1996). A new model of grief: Bereavement and biography. Mortality, 1(1), p.7-25 


\section{AOIR}

Selected Papers of \#AolR2019:

The $20^{\text {th }}$ Annual Conference of the

Association of Internet Researchers

Brisbane, Australia / 2-5 October 2019

\section{ROBOTIC PATHS TO A GOOD DEATH: FUNERALS WITH, BY, AND FOR ROBOTS}

Hannah Gould, Michael Arnold, Martin Gibbs, Tamara Kohn, Bjorn Nansen

The University of Melbourne

Across the globe, experiences of death, dying, disposition, and grief are increasingly inflected by digital technologies (Arnold et al. 2017), including robotic agencies. While popular visions of robotic technofutures drift between apocalypse and utopia, between the annihilation of human life and the transcendence of human mortality, this paper considers more mundane, but still significant, entanglements between robotics and death in the context of the funeral ceremony.

Recently, a number of experimental robotic technologies have emerged as possible means for securing a 'good death' in the $21^{\text {st }}$ century. This analysis is based on fieldwork within Japanese and US funerary industries during 2016-2019. In the following case studies, robots take on the funeral roles of attendee, religious specialist, and the dead. A 'good death' generally describes culturally normative modes of dying and memorialisation, although it is a shifting signifier with diverse meanings. Robotic agencies now dominate other dimensions of our lives, but can we trust them to deliver a 'good death' for our loved ones? Or, is our model of a 'good death' being transformed by robotic participation? The extra-human intimacies that robotic participation creates also prompt us to consider if and when the pliable notion of a 'good death' might extend to non-human robotic kin.

\section{CARL: Funerals with Robots}

Bailey and Walter argue that "the very presence" of those who knew the deceased at the funeral is one of the most important factors people use in assessing the quality of a funeral experience (2016). However, within increasingly globally dislocated communities, attending funeral services in person can place substantial burdens on time and finances. Travel to funerals by attendees is also one of the most significant factors contributing to the environmental impact of funerals (Keijzer 2017).

Gould, H. Arnold, M. Gibbs, M. Kohn, T. Nansen, B. (2019, October 2-5). Robotic paths to a good death: Funerals with, by, and for robots. Paper presented at AoIR 2019: The $20^{\text {th }}$ Annual Conference of the Association of Internet Researchers. Brisbane, Australia: AolR. Retrieved from http://spir.aoir.org. 


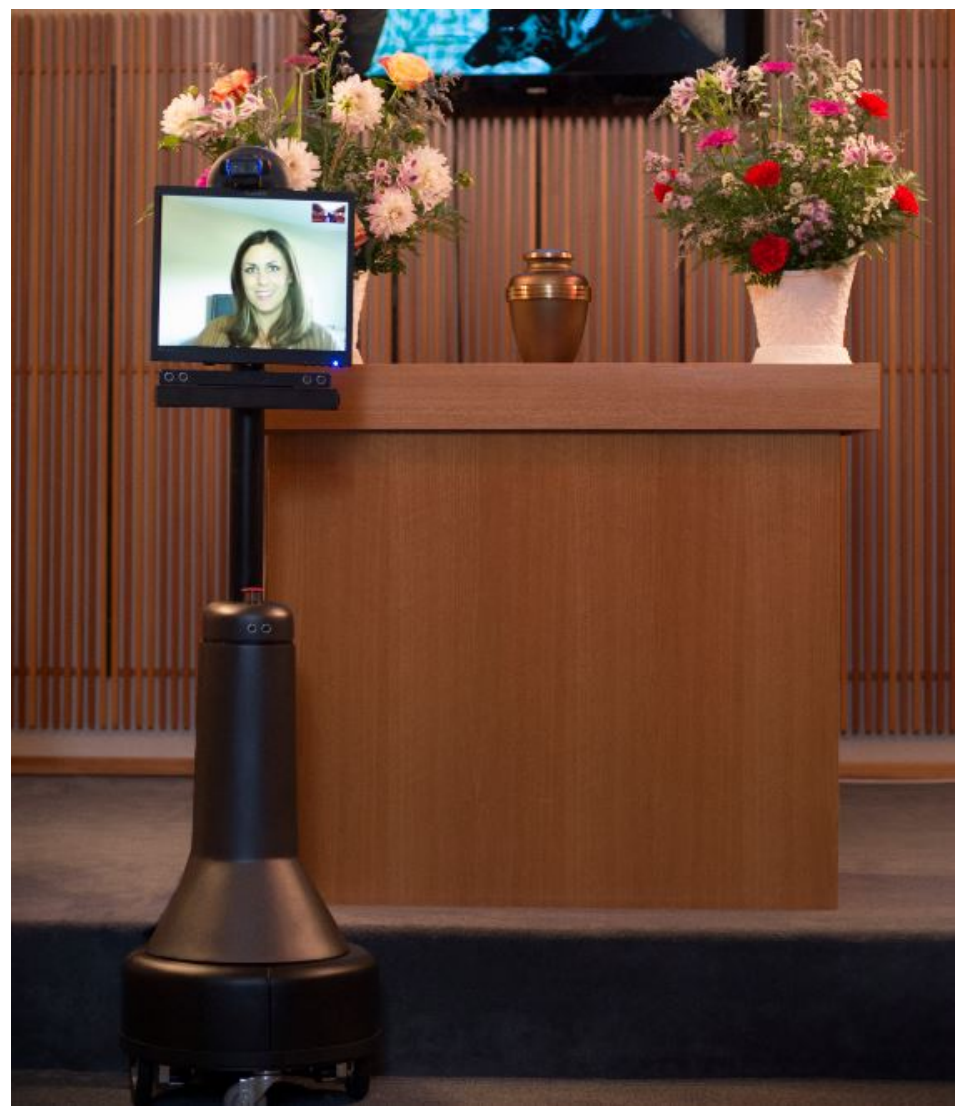

Figure 1. CARL deployed at funeral ceremony

Robots present one possible solution to this challenge, by creating a mobile telepresence for those unable to attend the service in person. 'CARL' (Figure 1) was showcased at various funeral industry expos in 2016. With a high-definition monitor for a 'head', together with a webcam and sound system mounted to a remote-controlled mobile pedestal 'body', adjustable to any height, CARL lets users deliver eulogies from the pulpit and mingle with other guests at the ceremony.

Many funeral service providers offer video recording and live streaming of funeral services, which can capture its formal aspects. However, they elide the social aspects of the funeral, which emerge from informal interactions between guests (Arnold et al. 2018: 112). The proposition offered by CARL was to provide social engagement at funerals for distantly-located guests, who would 'drive' the machine and make choices about how to engage. However, a relative novelty at the industry expo, CARL's commercial fate is uncertain.

\section{Pepper: Funerals by Robots}

At the 2017 International Funeral Industry Expo in Tokyo, large crowds witnessed the launch of a new service by plastics manufacturer Nissei Eco: Buddhist funeral rites conducted by a robot priest (Figure 2). The robot in question, Pepper, was launched in 2014 and has since become Japan's most prevalent commercial robot. Pepper's unique selling point is its ability to read human emotions via the analysis of human speech 
patterns and facial expressions. Dressed in silk robes with a mallet strapped to one arm, Pepper performed excerpts of the Heart Sutra, striking a large bell and wooden block in time.

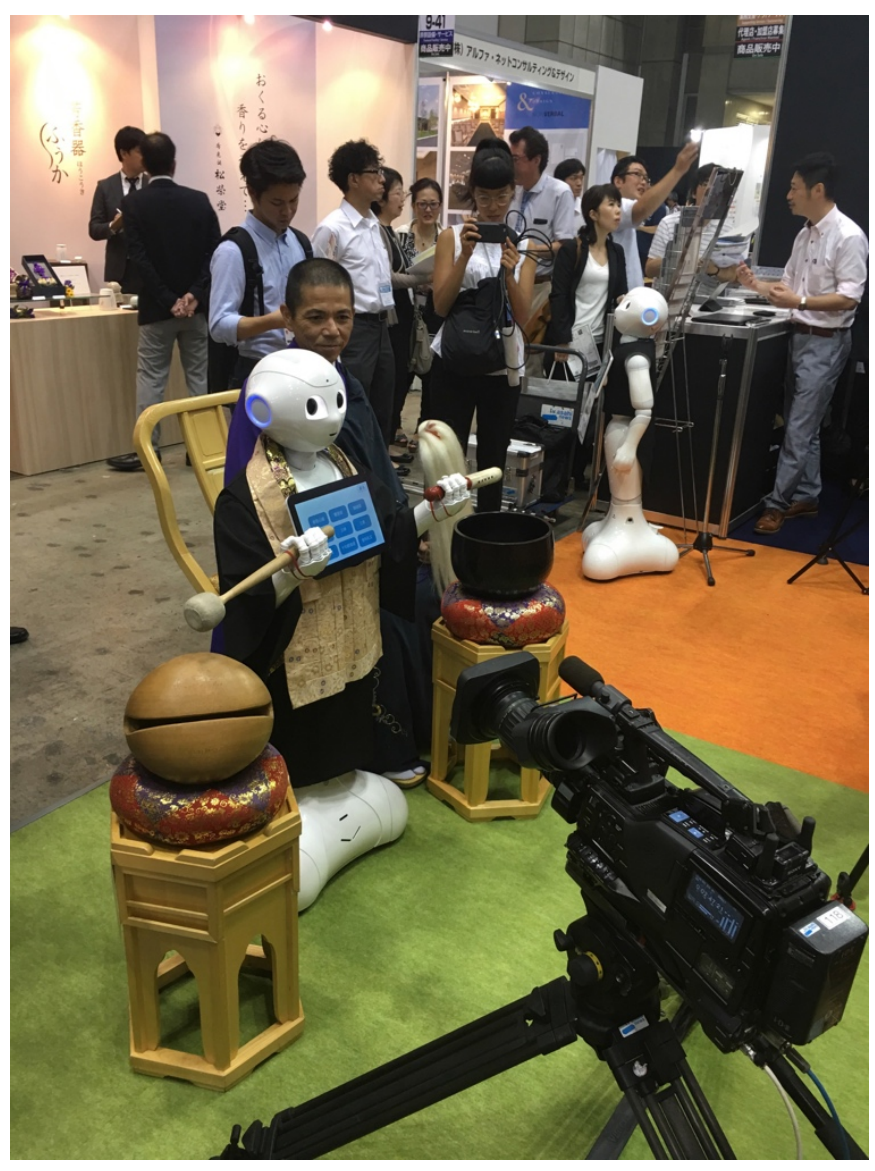

Figure 2. Pepper performs a demonstration funeral rite, Tokyo, 2017.

The service addressed growing vulnerabilities identified in Japanese social structure that have historically been relied upon to secure a 'good death' via the performance of extended funeral ceremonies. An increasingly isolated and ageing rural population and economic downturn has resulted in temple closures across Japan in recent years, and Nissei Esso presents Pepper as filling a serious deficit in the number of monks available to perform funerals. The socio-religious context of Japan helps explain why robotic funeral specialists make sense. In Japan, priests perform an increasingly limited role as ritual specialists within a broader, more secular ceremony (Suzuki 2000). Further, as Rambelli observes (2018) Japanese Buddhism has a long history of mechanising ritual performance, to a perceived increase, not decline, in its spiritual efficacy.

\section{AIBO: Funerals for Robots}

How might the participation of robots in human funerals affect how we view, and perhaps mark, the life and death of robots? 


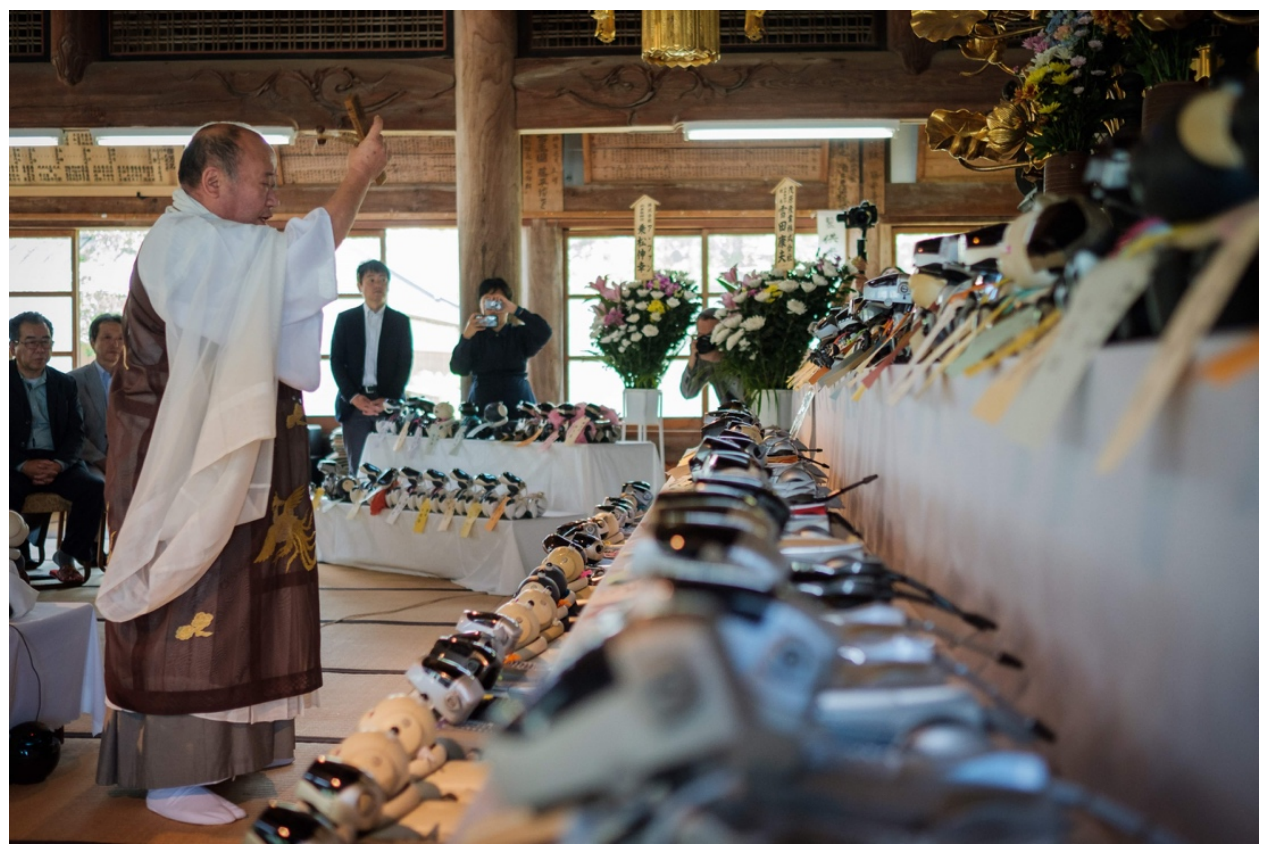

Figure 3. A Kofukuji priest performs kuyō for AIBO, 2018.

In May 2018, the 450-year-old Buddhist temple, Kofukuji, held a memorial service (kuyō) for over one hundred AIBO 'dog' robots (Figure 3). AIBO were produced by Sony from 1999-2006. Despite gaining a cult following, they never became commercially viable. In March 2014, Sony stopped producing replacement parts for the early models and many AIBO fell into disrepair and eventually 'died', despite efforts to crowdsource parts from 'donor' dogs (Robertson 2018: 164).

In Japan, there is a long history of Buddhist memorial rites marking the death of nonhuman persons. Historically, the list of entities deemed to require kuyō is subject to contestation and change, but has often included objects of intense use and human contact, such as professional tools (needles, scissors, eye glasses), or quasi-humanoid objects, like dolls and certain animals (whales, laboratory monkeys).

Social scientists have suggested that lay people's performance of memorial rites for objects are motivated by feelings of kinship and concern towards things, rather than Buddhist doctrine (Kretschmer 2000). This sense of kinship between human and nonhuman persons is not exclusive to the religious or cultural context of Japan. In 2013, American soldiers stationed in Iraq were reported to have held an elaborate funeral including a 21-gun salute for their fallen comrade, Boomer; a robot designed to locate and disarm explosives (Garber 2013).

\section{Conclusion}

One persistent definition of humanity's distinctiveness as a species is our awareness of mortality and its marking through ritual, but recently, participation in these rites has extended to include non-human robotic persons. In Japan, robotic priests borrow the authenticity of Buddhist performance; companion robots borrow the authenticity of their 
intimate interactions with the lives of their owners. They appear to create meaningful funeral experiences and contribute to a 'good death'. However, robotic funeral experiments in the US have been less successful, and those in Japan are not without their detractors. Death and its ritualization are a space in which the personhood of robots, and their ability to sustain authentic moral and social relations, are tested.

\section{References}

Arnold, M., Gibbs, M., Kohn, T., Meese, J., \& Nansen, B. 2017. Death and Digital Media. Routledge.

Bailey, Tara \& Tony Walter. 2016. Funerals against death. Mortality, 21(2): 149-166.

Garber, Megan. 2013. Funerals for Fallen Robots. The Atlantic, September 20.

Kretschmer, Angelika. 2000. Mortuary rites for inanimate objects: the case of Hari Kuyō. Japanese Journal of Religious Studies, 27(3/4), 379-404.

Keijzer, Elizabeth. 2017. The environmental impact of activities after life: life cycle assessment of funerals. The International Journal of Life Cycle Assessment 22(5): 715-730.

Rambelli, Fabio. 2018. Dharma Devices, Non-Hermeneutical Libraries, and RobotMonks: Prayer Machines in Japanese Buddhism. Journal of Asian Humanities at Kyushu University, 3, 57-75.

Robertson, Jennifer. 2018. Robot Reincarnation: Rubbish, Artefacts, and Mortuary Rituals. In Cwiertka, Katarzyna J. \& Ewa Machotka (eds.)., Consuming Life in PostBubble Japan: A Transdisciplinary Perspective, 153-173. Amsterdam University Press.

Suzuki, Hikaru. 2000. The Price of Death: The Funeral Industry in Contemporary Japan. Stanford University Press. 